\title{
Outcome of Clubfoot Correction at 'Walk for Life' Clinic of Mymensingh Medical College Hospital: A Four Year Review
}

\author{
Rahman $\mathrm{F}^{1}$, Chowdhury $\mathrm{MH}^{2}$, Kabir $\mathrm{H}^{3}$, Alam $\mathrm{J}^{4}$, Uddin $\mathrm{J}^{5}$, Evans $\mathrm{AM}^{6 *}$ \\ ${ }^{1}$ Armed Forces Medical College, Dhaka Cantonment, Dhaka, Bangladesh; ${ }^{2}$ Rajshahi Medical College \\ Hospital, Rajshahi, Bangladesh; ${ }^{3}$ Department of Orthopaedic, Abdul Hamid Medical College, Kishorganj, \\ Bangladesh; ${ }^{4}$ Shahid Ziaur Rahman Medical College, Bogura, Bangladesh; ${ }^{5}$ Chattogram Medical College \\ Hospital, Chattogram, Bangladesh; ${ }^{6}$ La Trobe University, Melbourne, Victoria, Australia
}

\begin{abstract}
Background: Every year in Bangladesh an estimated 3500 - 4000 children are born with a clubfoot deformity, which is approximately one of every 1000 children born in Bangladesh. Left untreated, the condition leads to lifelong deformity causing individual disability and potential unproductivity. Affected children grow up as burden to the family and ultimately leads to significant poverty.

Methods: This study was conducted at the 'Walk for Life' (WFL) clinic Mymensingh Medical College Hospital (MMCH) during February 2011 to December 2014. The non-surgical Ponseti method was applied by the orthopaedic surgeon and physiotherapist. Follow-up for relapsed deformity in children who were treated in 2011 occurred in 2015.

Results: A total of 577 children comprised of $175(30.32 \%)$ female and $402(69.7 \%)$ male, a gender ratio 1F: 2.29 M. Completions of treatment data were available for 471 children, as 106 had dropped out at different stages of the treatment cycle. Sadly, 12 children had died. In $440(76.4 \%)$ children, the parents' monthly income approximated Tk. 5000, and 364 (82.8\%) lived in tin shed houses. The parents with lowest incomes predominated for children with clubfoot. Most parents 383(66.4\%) were labourers, small business and service workerswith the lowest income. A family history of clubfoot deformity was found in $8.3 \%$, of which $2.8 \%$ were cousins, $1.7 \%$ were an uncle. The average number of corrective plaster casts applied before the tenotomy was $3.32 \%$ in 477 children. In $73.0 \%$ of childrenthree to six casts were used for initial correction. An Achilles tenotomy was performed in $81.0 \%$ children, $18 \%$ did undergo a tenotomy and one child had multiple tenotomies.Four years following of initial treatment, 99 children were reviewed, and 98 were walking and running. Parents' satisfaction was $96.0 \%$. Thirteen percent children showed relapse signs. Most of the children treated at the WFL clubfoot clinic were walking normally four years after initial treatment.

Conclusion: The Ponseti method is found to be very effective and especially for a developing country like Bangladesh. Poverty and housing condition may play a role in clubfoot disease. The dropout rate across the treatment cycle was $18.4 \%$, warranting closer evaluation. The patronage of the Glencoe Foundation WFL clinics since 2009, played an important role in relieving thousands of Bangladeshi children from disability.
\end{abstract}

Keywords: Clubfoot, Ponseti method, Relapse

\section{Introduction}

Clubfoot is a complex, congenital foot deformity of the foot also known as 'congenital talipesequinovarus' (CTEV). Visually, the foot affected by clubfoot appears to be twisted inwards and downwards. The foot is shorter than a normal

*Correspondence: Dr A M Evans, School of Science, Health and Engineering, La Trobe Universit, Melbourne,Australia.e-mail:angela.evans@latrobe.edu.au ORCID: https://orcid.org/0000-0001-8101-9456 one and the calf muscles of the affected limb will be smaller. ${ }^{1}$ Every year in Bangladesh an estimated 3500 - 4000 children are born with a clubfoot deformity, with a global incidence of 1.5 per 1000 livebirths. $^{2}$ Untreated, clubfoot leads to lifelongdeformity causing individual disability and unproductivity. This causes the children to grow up as burdens of the family and ultimately leads to significant poverty. 
During 2009 to 2017, over 19,500 children with clubfoot were enrolled at WFL clinics across Bangladesh. ${ }^{3}$ WFL is a charitable project of the Glencoe Foundation, with clinics appended to the Government of Bangladesh initiatives, and acknowledged by the Government as the National Clubfoot Programme in Bangladesh. The preferred treatment of congenital idiopathic talipes equinovarus (clubfoot) is the nonsurgical Ponseti method, which has revived interest in infantile clubfeet. $^{4,5}$ Ponseti method of manipulation and plaster casting is very effective in correcting clubfoot deformity. It is especially important in developing countries and well-trained staff can manage the cases effectively by manipulation and cast application. ${ }^{6}$

However, surgical treatment in the form of posteromedial release, is often undertaken after failure of conservative measures, but this should be avoided and the 'joint-sparing' Ponseti method repeated when required. Several factors such as genetic predisposition, gestational abnormalities and a variety of histological abnormalities seem to be related to genesis. ${ }^{7-8}$ Nonetheless, the true cause of CTEV remains unknown. ${ }^{9}$

As reported previously, treatment is generally unaffordable for the families. ${ }^{10}$ Since the inception of 'Walk for Life' at Mymensingh Medical College Hospital (MMCH) in 2011, 634 children were treated with Ponseti method, to end 2014. Ponseti method has become the 'gold standard' of care for the treatment of CTEVand has been well circulated all over the world, especially the developing world where most clubfoot children live. ${ }^{11}$ Previous reports have indicated the challenges and successes of implementing the Ponseti technique in this poor and populous country. There are records of conservative treatment dating back to $400 \mathrm{BC}$ performed by Hippocrates by means of manipulations followed by immobilization. ${ }^{12}$

In the $21^{\text {st }}$ century, surgical correction of clubfeet has been firmly denounced. ${ }^{13}$ Retrospective review and prospective studies have both shown the poor outcomes, in terms of pain and function from the Posterior Medial Release (PMR) surgical procedures. ${ }^{14}$ The non-surgical Ponseti method has been extensively investigated and found to give the best clinical outcomes, and also to be a more cost effective, when compared to surgery. ${ }^{15,16}$ It is imperative to note the mid-term results of this large-scale project, indicating its extraordinary effectiveness, with $99 \%$ of treated children now walking independently two years after treatment. ${ }^{17}$ This study was undertaken for some baseline characteristics and to evaluate the success of Ponseti method in Bangladesh, and to explore characteristics of the affected population.

\section{Materials and Methods}

This study was conducted as a retrospective and cross-sectional reviewof the WFL clinicat MMCH between 2011 and 2015. Ethical approval was taken from Ethical Review Committee of Mymensingh Medical College. $\mathrm{MMCH}$ is a tertiary referral teaching hospital in greater Mymensingh area in the north east to the capital of Bangladesh, covering almost 25 million people. All children treated at WFL at $\mathrm{MMCH}$ during February 2011 to December 2014 were included. All children were aged from birth to three years.

Relevant demographic and clinical information were documented for this study.Family history, housing condition, clubfoot severity score (Pirani method), need for tenotomy, number of casts to get correction and complications were recorded.

Children with clubfoot and an associated syndrome, and those who had had previous surgery for clubfoot, were excluded from this study. The standard Ponseti method was applied, with follow up by the Orthopaedic surgeon and Physiotherapist.

Follow up for relapses for those children treated in 2011 occurred when the parents brought their children to the clinic periodically. Ultimately, all children who had commenced treatment in 2011 were contacted for review in 2015.

For the follow-up reviews, WFL made phone calls to all the children's parents over mobile (cell) phone, requesting them to bring their child to the clinic. WFL covered the transport costs. At the review appointments, information was collected by face to face interview with parents and someolder children could also answer questions.

Children's physical ability to squat, walk, run, and use stairs were assessed by asking their parents and seeing the children's movements. A previously 
developed assessment tool was used for this purposeThe Bangla Clubfoot assessment tool. ${ }^{12}$

Data were entered on an electronic spreadsheet using both Microsoft Excel and SPSS software for analyses.

Descriptive and frequency statistics were used for demographic data, including both whole scores and percentage. Mean scores were reported at follow-up.

\section{Results}

Clubfoot has from long been an unsolved clinical challenge for the Orthopaedic surgeons. The problem is more serious in developing countries on account of late presentation, higher rate of drop outs from treatment and superstitious beliefs attached to this congenital problem. ${ }^{18}$

In this study, a total of 577 clubfoot children reported to WFL clinic $\mathrm{MMCH}$ from 2011 to 2014. Of the total 577 patients $175(30.32 \%)$ were female and $402(69.7 \%)$ were male. Gender ratio was $1 \mathrm{~F}: 2.29 \mathrm{M}$.

There was no inherent family history of clubfoot in $91.7 \%$ of affected children, and only $8.3 \%$ had family history, of which $2.8 \%$ cousins, $1.7 \%$ uncle (table II).

Table II: Inherent Family History of Club Foot $(\mathrm{n}=577)$

\begin{tabular}{|c|c|c|c|c|c|c|c|c|c|}
\hline \multicolumn{10}{|c|}{ Relationship } \\
\hline & $\begin{array}{c}\text { No } \\
\text { Inherent } \\
\text { History }\end{array}$ & Mother & Father & $\begin{array}{c}\text { Sibling, } \\
\text { Cousin, Uncle } \\
\text { (combined) }\end{array}$ & Sibling & $\begin{array}{l}\text { Grand } \\
\text { Parent }\end{array}$ & Cousin & Uncle & \\
\hline $\begin{array}{c}\text { Family } \\
\text { History } \\
\text { Clubfoot }(\%)\end{array}$ & $\begin{array}{c}529 \\
(91.7 \%)\end{array}$ & $\begin{array}{c}2 \\
(0.3 \%)\end{array}$ & $\begin{array}{c}4 \\
(0.7 \%)\end{array}$ & $\begin{array}{c}1 \\
(0.2 \%)\end{array}$ & $\begin{array}{c}12 \\
(2.1 \%)\end{array}$ & $\begin{array}{c}3 \\
(0.5 \%)\end{array}$ & $\begin{array}{c}10 \\
(1.7 \%)\end{array}$ & $\begin{array}{c}16 \\
(2.8 \%)\end{array}$ & $\begin{array}{c}577 \\
(100 \%)\end{array}$ \\
\hline Total & 529 & 2 & 4 & 1 & 12 & 3 & 10 & 16 & 577 \\
\hline
\end{tabular}

The average age at the time of first cast was 1.75 (0.96) years with approximately half of children $(54.5 \%)$ less than three months, and three-quarters $(78 \%)$ up to one year of age (table III).

Table III:Children by age at $1^{\text {st }}$ cast $(n=471)$

\begin{tabular}{lcc}
\hline \multicolumn{1}{c}{ Age at $\mathbf{1}^{\text {st }}$ cast } & Frequency $(\mathbf{n})$ & $\%$ \\
\hline $0-3$ months & 260 & 55.2 \\
4 months -1 year & 106 & 22.5 \\
$1-2$ years & 70 & 14.9 \\
$2-3$ years & 35 & 7.4 \\
Totals & 471 & 100.0 \\
\hline
\end{tabular}

Mean age 1.75 years (SD 0.96)

Within the 99 reviewed patients, average age at first cast was 1.01 years, with 31 less than three months old, and 57 up to age one year.

Of the 577 children who commenced treatment at $\mathrm{MMCH}, 471$ (81.6\%) completed all facets of the three-year treatment cycle. Drop out occurred at different treatment phases in 106 children: 43 during casting phase, 51 during maintenance brace phase. Twelve children died due to illness unrelated to clubfoot deformity: five during casting phase, seven during maintenance brace phase.

This study revealed that $440(76.4 \%)$ patient's parents had monthly income approximating TK 5000 per month of which $364(82.8 \%)$ had tin shed houses with other categories of income group that totals $469(81.3 \%)$ of tin shed, that showed least income group had maximum number of clubfoot patients. Whereas highest income group had only $10(1.6 \%)$ patients those had tin shed and building houses of their parents (table I).

Table I: Distribution of Children by condition of Housing and Parents' income $(n=577)$

\begin{tabular}{cccccc}
\hline $\begin{array}{c}\text { Family } \\
\text { income } \\
\text { (Taka / } \\
\text { month) }\end{array}$ & $\begin{array}{c}\text { Bamboo/ } \\
\text { wood }\end{array}$ & Brick & Mud & Tin & Total \\
\hline $0-5000$ & 24 & 28 & 24 & 364 & 440 \\
& $(5.2 \%)$ & $(6.3 \%)$ & $(5.7 \%)$ & $(82.8 \%)$ & $(76.4 \%)$ \\
$5000-$ & $1(0.9 \%)$ & 18 & 3 & 81 & 103 \\
10,000 & $(32.1 \%)$ & $(3.9 \%)$ & $(78.6 \%)$ & $(17.9 \%)$ \\
$10,000-$ & 0 & 5 & 0 & 19 & 24 \\
20,000 & & $(20.8 \%)$ & & $(4.1 \%)$ & $(4.2 \%)$ \\
$>20,000$ & 0 & $5(50 \%)$ & 0 & $5(50 \%)$ & 10 \\
& & & & 469 & 577 \\
Total & 25 & 56 & 27 & $(81.3 \%)$ & $(100 \%)$ \\
\hline
\end{tabular}

Note: July 2017: 5000 Taka = US\$62

Parents' occupation were predominately day labourers, and small business and were least income peoplewere 383 (66.4\%).

For the 99 children reviewed from 2011, the average number of casts was between three and six $73 \%$ (72/99). One child had 17 casts, 16 children had between seven to 11 casts and 10 had only one to two casts (table IV). 
Table IV: Number of casts applied before Tenotomy $(\mathrm{n}=471)$

\begin{tabular}{ccc}
\hline $\begin{array}{c}\text { Grouped cast } \\
\text { numbers }\end{array}$ & Frequency (n) & $\%$ \\
\hline $1-2$ & 9 & 1.6 \\
$3-6$ & 138 & 23.9 \\
$7-11$ & 109 & 18.9 \\
$12-16$ & 133 & 23.1 \\
$>17$ & 88 & 15.3 \\
Totals & 471 & 100.0 \\
\hline Mean 3.32 casts (SD 1.13) & &
\end{tabular}

Overallfor the 471 children, the average number of casts applied was $3.32(1.1 \%)$ before the tenotomy, and up to six casts were required in 147/471 children.

Out of 99 reviewed children commencing treatment in $201180 / 99(80.8 \%)$ children had a percutaneous tenotomy, 18/99 (18.2\%) did not, and one child have multiple tenotomies.

Parents' satisfaction was observed in this study and it was found that $435(91.2 \%)$ were satisfied with the overall treatment of their children. A total of $30(6.2 \%)$ parents were not completely satisfied with their child's treatment.The four-year review of 99 children found a similar result, with $96 \%$ parents satisfied.

Most of the children reviewed after four years, 38 (38.4\%) were aged between four and five years, 25 $(25.3 \%)$ were a year older, and $22(22.2 \%)$ a year younger.

Parents'opinion of their child's physical abilityfour years after treatment returned the following: 80/99 could weartheir chosenshoes, 8/99 could not wear their chosen shoes, 11/99 parents did not know, and could not afford shoes for their child. Regarding activity, 97/99 children played, 84/99 could fully squat, 98/99 children walked and ran. Overall, 97/99 parents were happy on the management and treatment of the clinic (table V).

Table V: Parents' Observation on their child Progress $(n=99)$

\begin{tabular}{|c|c|c|c|c|}
\hline $\begin{array}{c}\text { Parents } \\
\text { Observation }\end{array}$ & Yes & No & $\begin{array}{l}\text { Do not } \\
\text { know }\end{array}$ & Mean \\
\hline $\begin{array}{c}\text { Child wear shoes } \\
\text { of choice }\end{array}$ & $\begin{array}{c}80 \\
(80.8 \%)\end{array}$ & 8 & 11 & 44 \\
\hline Child play & $\begin{array}{c}97 \\
(97.9 \%)\end{array}$ & 2 & & 98 \\
\hline Squatting & $\begin{array}{c}84 \\
(84.8 \%)\end{array}$ & $\begin{array}{c}14 \\
(14.14 \%)\end{array}$ & 1 & 84 \\
\hline Walking & $\begin{array}{c}98 \\
(98.9 \%)\end{array}$ & 1 & & 99 \\
\hline Running & $\begin{array}{c}98 \\
(98.9 \%)\end{array}$ & 1 & & 99 \\
\hline Happy & $\begin{array}{c}96 \\
(96.9 \%)\end{array}$ & 3 & & 97 \\
\hline
\end{tabular}

Not all children were available for the four-year review. Of the 151 contacted, 48 could not be located, two children had sincedied, 103 reported of which 4 children had syndromic foot and were excluded from this study. Of the 99 included children, 13 (13.1\%) had developed relapse signs and were managed accordingly, with repeated Ponseti method, and minor surgery if indicated.

\section{Discussion}

The children who were treated successfully in 2011 were walking normally, mixing with other children, growing toward adolescence, and enjoying are habilitated life.

Remarkably, the mothers or fathersthemselves afflicted with clubfoot deformitywere found frustrated not for their own disability, but for their child. The girls with clubfoot were not being married due to this 'clubfoot curse', and suffered lasting despair. Untreated clubfoot causes a critical situation for people in Bangladesh, which has been effectively improved by the Glencoe Foundation, establishing 42 WFL clinics across the country. Since 2009, over 19,500 children were treated (as onMay, 2017), and most were walking and would be able to live a normal life.

This study confirmed the gender ratio disparity inherent in CTEV, as did Mejabi et al. who found $38(62.3 \%)$ male and $23(37.7 \%)$ female with the gender ratio of 1.7 M:1 F. Similarly, Pulak and Swamy found $80 \%$ male and $20 \%$ female with a gender ratio of $4 \mathrm{M}: 1 \mathrm{~F}^{20}$ The precise incidence of clubfoot in Bangladesh per se is not established, but recent global data can confidently be adopted ie 1-2:1000 births. In Bangladesh, and other developing nations, females clubfoot patients are not given due attention, due to social bias and wariness favouring male children, which may also influence reported gender ratios. ${ }^{21}$

This study showed thatthree-quarters of parents had a very low monthly income, with most living in tin shed houses. The lowest incomes, poor standard housing majority also had maximum proportion of clubfoot children. Supporting this study, a previous report found that approximately half of the family incomes were between TK 5000 to $10,000 .{ }^{22}$ The very likely reason that these very low income families brought their children with 
clubfoot deformity to the WFL clinic is that the treatment was provided totally free of cost.

Family history of clubfoot in this study wassimilar to that found by Honeinbut lower than reported by other family-based studies. ${ }^{23-24}$

Morcuende et al reported the average age at first cast as three months. ${ }^{25}$ Similarly, Lara et al reported the average age at first cast as between 3.2 and 5.4 months. ${ }^{9}$ This study from $\mathrm{MMCH}$ returned an older average age at first cast, as WFL were being established and public awareness still growing. From many perspectives, a younger age at first cast is preferable for easier clubfoot management. It has been recommended that treatment should begin within first 15 days of life. ${ }^{26}$

Herzenberg et al found the mean number of caststo be seven, another study found a mean of five corrective casts. ${ }^{26-27}$ In contrast, this study foundan average of three and six corrective casts required, including the four year review cohort. Recently, with more experience and an adopted evidencebased modification, WFL has begun changing plaster casts at shorter intervals. ${ }^{13}$

The tenotomy rate in this study was $80 \%$, comparing favourably with $67 \%$ in Laara et al, ${ }^{9}$ $57 \%$ in Chu et al. $^{26}$ It should be noted that $\mathrm{Dr}$ Ponsetiadvised and performed the tenotomy in more than $90 \%$ of cases. ${ }^{9}$

Parents' satisfaction is an important factor in any paediatric condition requiring their cooperation for effective intervention. In this study parent satisfaction was very high, similarly to the findings of Bor $\mathrm{N}$ et al, who also found that parents indicated high satisfaction with the treatment of their children with Ponseti method. $^{27}$ Further, Evans et al, found $97 \%$ parents were happy with their children's improvement with treatment, where as Rahman et al, found that half of parents were highly satisfied after receiving treatment for their child's clubfoot deformity. ${ }^{10,22}$

The positive effect of public awareness effortshas been apparent across WFL clinics in Bangladesh, as the age of presentation of children has reduced. Most children reviewed were aged between three and six years. By contrast, Rahman et al, reviewed
90 percent ofchildren aged less than three years. ${ }^{21}$ Since 2011, when the WFL clinic at $\mathrm{MMCH}$ began, the age of initial presentation of children with clubfoot has reduced withmost now aged less than six months at the time of first casts.

This study addressed and appreciated parents' opinions, and what becomes relevant for them as the children become older. Being able to wear their choice shoes, being able to play with other children, to squat (for play, toileting, eating), and being able to walk and run like other same- aged children were all important factors for parents and related to their reported happiness. Rahman et al also mentioned the importance for parentsfor their children to be able to stand, walk and do other activities like healthy babies. ${ }^{22}$

Relapsing clubfoot deformity is not uncommon. Those found with relapse signs in this study, were all given further treatment. Rahmanet $\mathrm{al}^{22}$ returned three-fold higher relapse rate of $37 \%$, and Morcuende et $\mathrm{al}^{13}$ found $25 \%$ relapses. Current knowledgeexpresses that relapses are not always due to non-compliance with treatment, but due to underlying connective tissue 'stiffness'.

\section{Conclusion}

Based on the study findings, it may be concluded that the Ponseti method has been widely found to be very effective both clinically and economically, with greatest gains and advantage for developing countries like Bangladesh. Poverty, housing conditions, and nutrition may contribute to 'clubfoot disease' and warrant further prospective study. The Bangladesh Government can continue to support WFL clinics where Orthopaedic surgeon and Physiotherapists are available, to alleviate the burden of this correctable disability.

\section{Acknowledgements}

The research group acknowledges all WFL clinics, the significant patronage of the Glencoe Foundation (Colin MacFarlane, Founder), all WFL volunteers, and all WFL donors.In addition, WFL acknowledge the role of the late Dr Frederick R. Dietz, our respected colleague and friend.

Conflict of Interest: Authors declare no conflict of interest. 


\section{References}

1. Cooke S, Balain B, Kerin C, Kiely S Clubfoot. Orthop Trauma. 2008; 22: 139-49.

2. Smythe T, Kuper H, Macleod D, Foster A, Lavy C. Birth prevalence of congenital talipesequinovarus in low- and middle-income countries: a systematic review and meta-analysis. 2017; 22:269-85. DOI: dx.doi.org/10.1111/tmi.12833

3. Ford-Powell V, Barker S, Khan SI, Evans AM, Dietz FR. The Bangladesh clubfoot project: the first 5000 feet. J Pediatr Orthop 2013;33:e40-4.

4. Lyn Staheli (ed). Clubfoot: Ponseti management. $3^{\text {rd }}$ edition 2009, Global HELP: 4-27.www.global-help.org

5. Colburn M, Williams M. Evaluation of the treatment of idiopathic clubfoot by using the Ponsetimethod. J Foot Ankle Surg, 2003, 42: 259-67.

6. Pulak S, Swamy MKS. Treatment of Idiopathic Clubfoot by Ponseti Technique of manipulation and serial plaster casting and its critical evaluation. Ethiop J Health Sci Jul. 2012; 22: 77-84.

6. Dietz F. The Genetics of Idiopathhic Club Foot. Clin Orthop Relat Res 2002; 401: 39 - 48.

7. Cummings RJ, Davidsons RS, Armstrong PF, Lehman WB. Congenital Clubfoot. J Bone Joint Surg Am 2002; 84: $290-308$.

8. Ippolito E, Ponseti IV. Congenital Clubfoot in the human fetus - A histological study. J Bone Joint Surg Am 1980; 62: 8 - 22 .

9. Lara LCR, Netob DJCM, Pradoc FR, Barretoc AP. Treatent of idiopathic congenital clubfoot using Ponseti method: Ten years of experience. Rev Bras Orthop Sao Paulo.2013; 48: 362 - 67.

10. Evans AM, Chowdhury MMH, Kabir MH, Rahman MF. Walk for life - the National Clubfoot Project of Bangladesh: the four year outcomes of 150 congenital clubfoot cases following Ponseti method. J Foot Ankle Res. 2016; 9: 42

11. Zeno AG, Sorin BE. Idiopathic club foot treated with the Ponseti method. Histological analysis after achilles Tendon tenotomy in rats with club foot. J Pediatr. 2014;17:67 - 68 .

12. Evans AM, Perveen R, Ford-Powell VA, Barker S. The Bangla Clubfoot tool: a repeatability study. J Foot Ankle Res. 2014; 7: 1-6.

13. Morcuende JA, Dolan LA, Dietz FR, Ponseti IV. Radical reduction in the rate of extensive corrective surgery for clubfoot using the Ponseti method. Pediatr. 2004; 113: 376 - 80.

14. Halanski MA, Davison JE, Huang JC, et al. Ponseti method compared with surgical treatment of clubfoot: a prospective comparison. J Bone Joint Surg Am. 2010; $92: 270-78$.

15. Carrol NC. Clubfoot in the twentieth century: where we were and where we may be going in the twenty first century. J Pediatr Orthop B. 2012; 21:1- 6.

16. Dobbs MB, Gurnett CA. Update on clubfoot: etiology and treatment. Clin Orthop. 2009; 467: $1146-53$.

17. Perveen R, Evans AM, Ford-Powell V, Dietz FR, et al. The Bangladesh Clubfoot project: audit of 2year outcomes of Ponseti treatment in 400 children. J Pediatr Orthop. 2014; 34: $720-25$.

18. Pulak S, Swamy MKS. Treatment of idiopathic clubfoot by Ponseti Technique of manipulation and serial plaster casting and its critical Evaluation. Ethiop J Health Sci. 1012; 22: 77 - 84 .

19. Mejabi JO, Esan O, Adegbehingbe OO, Orimolade EA, Asuquo J, Badmus HD, Anipole AO. The Pirani Scoring System is effective in assessing severity and monitoring treatment of Clubfoot in children. BJMMR. 2016; 17: 1- 9.

20. Pulak S, Swamy MKS. Treatment of idiopathic Clubfoot by Ponseti Technique of manipulation and serial plaster casting and its critical evaluation. Ethiop J Health Sci 2012.; 22: 77 - 84.

21. Yoyos DI. A Four-year Review of Delayed Initial Treatment ofPatients with Congenital Talipesequinovarus in a General Hospital. Malaysian Orthopaedic Journal. 2015;9: 11-13. DOI: dx.doi.org/10.5704/MOJ.1503.007

22. Rahaman M, Haque M, Rahman MS, Bhuiyan R, Huda MM, Islam KM. Pattern of Clubfoot deformity and adherence to Ponseti treatment among children with clubfoot deformity. MOJ Orthop Rheumatol. 2015; $2: 20-22$.

23. Honein MA, PaulozziLJ,Moore CA. Family History, Maternal Smoking, and Clubfoot: An Indication of a Gene-Environment Interaction. Am J Epidemiol 2000; $152: 658-65$.

24. Palmer RM. Hereditary clubfoot. Clin Orthop. 1964; 84: $9-13$.

25. Morcuende JA, Dobbs MB, Frick SL. Results of the Ponseti Method in patients with clubfoot associated with arthrogryposis. Iowa Orthop J. 2008; 28: 22- 26.

26. Chu A, Labar AS, Sala DA, Van Bosse HJ, Lehman WB. Clubfoot classification: correlation with Ponseti cast treatment. J Pediatr Orthop. 2010; 30: 695 - 99.

27. Herzenberg JE, Radler C, Bor N. Ponseti versus traditional methods of casting for idiopathic clubfoot. J Pediatr Othop 2002; 22: $517-21$.

28. Bor N, Coplan JA, Herzenberg JE. Ponseti Treatment for Idiopathic Clubfoot Minimum 5-year Followup. Clin Orthop Relat Res. 2009; 467:1263-70. 